\title{
The effect of thriphala, a herbal Ayurveda formulation, on serum lipids, in patients on a maintenance dose of atorvastatin for hyperlipidaemia: a randomized controlled trial
}

\author{
R A I Ekanayaka ${ }^{1}$, A D C S Rupasinha ${ }^{2}$, M R Sooriyarachchi ${ }^{3}$, C Goonaratna ${ }^{4}$
}

\begin{abstract}
Introduction Thriphala, a herbal medicinal formulation, is a bedrock of Ayurveda therapeutics with many postulated benefits.

Objectives We performed a clinical trial to test the effects of Swastha Thriphala ${ }^{\circledR}$, a proprietary preparation of thriphala, on serum lipid parameters in patients receiving atorvastatin.
\end{abstract}

Methods Consenting adults receiving a maintenance dose of atorvastatin 10mg (Atorlip ${ }^{\circledR}$ ) daily from a clinic of the Institute of Cardiology, National Hospital of Sri Lanka for lipid regulation, were randomly assigned, after counselling, to receive either the proprietary herbal medicinal product Swastha Thriphala ${ }^{\circledR}$ (Treatment Group, $\mathrm{n}=101$ ) or a placebo (Control Group $n=97$ ), at the stipulated dose daily, for three calendar months.

Results In the treatment group $(\mathrm{n}=101)$ the addition of a proprietary preparation of thriphala formulated as caplets of Swastha Thriphala ${ }^{\circledR}$, in the standard daily dosage for three months, as an adjunct to atorvastatin 10mg, had a significant $(\mathrm{p}<0.0001)$ reduction in the mean total blood cholesterol, mean cholesterol/HDL ratio $(p<0.0001)$, and mean nonHDL-cholesterol $(\mathrm{p}<0.0001)$ when compared to the Control Group $(n=97)$ receiving placebo caplets in the same daily dose, with atorvastatin $10 \mathrm{mg}$, for the same period. In the Treatment Group mean HDL, LDL, HS-CRP, and triglyceride concentrations showed non-significant reductions, and nonsignificant elevations in the Control Group.

Conclusions Swastha Thriphala ${ }^{\circledR}$ when used in the stipulated dosage as an adjunct to atorvastatin $10 \mathrm{mg}$ daily, significantly enhances its cholesterol reducing action in patients. The use of Swastha Thriphala ${ }^{\circledR}$ as single therapy for lipid regulation, and the mode of its action deserve investigation.

Ceylon Med J 2017;62: 128-140

DOI: http://doi.org/10.4038/cmj.v62i3.8516

\section{Introduction}

Hyperlipidaemia is a serious problem of epidemic proportions worldwide as one of the major risk factors for cardiovascular disease [1]. Cardiovascular disease is the leading cause of morbidity and mortality in the world [2]. Combined with lifestyle modifications lipid-regulating medication is a key component of both primary and secondary prevention of cardiovascular disease. Statins are the undisputed first-line drugs for lipidregulation [1]. Statins provide a high level of efficacy and effectiveness with acceptable affordability. However, they have a large number of side-effects such as muscle cramps and myalgia (which are relatively frequent but mild), and others such as myositis, myopathy, rhabdomyolysis, altered liver function, jaundice and hepatitis, that are less common or rare, but problematic $[1,2,3]$.

The primary rationale for our study derives from a major recent WHO publication that has emphasized the need for robust research and clinical trials to evaluate herbal medicinal products, noting that they have been, and are, a valuable source of potentially useful remedies [4]. We have been encouraged also by the fact that at least four successful clinical trials with Sri Lankan Ayurveda medicinal products have been recently published in prestigious journals $[5,6,7,8]$.

Several promising Ayurveda herbs and herbal preparations such as cinnamon (Cinnamomum verum) and garlic have produced significant reductions in total serum cholesterol (TC) and low density lipoproteins (LDL), with or without an increase of high density lipoproteins (HDL), in both human and experimental animal studies [9-12]

\footnotetext{
${ }^{1}$ Institute of Cardiology, National Hospital of Sri Lanka, ${ }^{2}$ Link Natural Products (Pvt) Ltd., ${ }^{3}$ Department of Statistics, University of Colombo and ${ }^{4}$ Ceylon Medical College Council, Colombo, Sri Lanka.

Correspondence: CG, E-mail: <si7np5e@gmail.com>. Received 19 November 2016 and revised version accepted 19 March 2017.
} 
In a study in experimentally induced atherosclerosis in rabbits, formulations of three herbal products reduced not only blood cholesterol and other lipids, but also cholesterol content in the liver and plaques in the aorta and coronary arteries [13]. The three herbal components tested in this study were the dried fruits of Terminalia chebula (Sinhala: Aralu), Terminalia bellerica (Sinhala: Bulu), and Phyllanthus emblica (Sinhala: Nelli). These three fruits are the components of thriphala, a several centuries old herbal preparation, which is a cornerstone of Ayurveda therapeutics. Thriphala, as well as its individual components separately, have shown significant hypolipidaemic properties in human volunteers, as noted in a recent monograph [14].

Thriphala has been described in the ancient Ayurveda text Charaka Samhitha, circa BC 1500, as a thridosa rasāyanaya, meaning a beneficial formulation for harmonising the three humours (or constitutional elements) in the Ayurveda system of medicine, namely vāta, pitta and kapha [15]. Its major benefits are described as harmonising gastrointestinal and hepatic functions, retarding the ageing process, promoting longevity, and the maintenance of good health [16].

Recent scientific studies have shown that thriphala has promising free radical, scavenging, antioxidant, anti-inflammatory, antipyretic, analgesic, antibacterial, and anti-stress effects. These studies have validated many of the properties claimed by historical evidence and the more recent ethno medical studies [17].

We chose thriphala, formulated as caplets in the proprietary preparation Swastha Thriphala ${ }^{\circledR}$, for our study because of its convenience in use, and because its consumption locally, both as a prescription medicine and as an over-the-counter medicine, is over 10 million caplets annually.

The primary objective of our study was to see the effects of the proprietary Ayurveda formulation Swastha Thriphala ${ }^{\circledR}$ on blood lipids when used as an adjunct to atorvastatin in patients requiring lipid regulation. The secondary objectives were to assess compliance of participants to the said Ayurvedic formulation, and its incidence of sideeffects.

\section{Methods}

We designed a prospective, randomised, double-blind placebo-controlled and parallel allocation clinical trial to assess the effects of the proprietary Ayurveda medicinal preparation, Swastha Thriphala ${ }^{\circledR}$, on blood lipid variables in patients receiving a maintenance dose of atorvastatin
$10 \mathrm{mg}$ daily for hyperlipidaemia from a clinic in the Institute of Cardiology, of the National Hospital of Sri Lanka.

Consenting patients aged between 35 and 70 years were counselled by one author (C.G.) in small groups of $6-12$ individuals, the actual number depending on recruitment from each routine weekly clinic. Venous blood $10 \mathrm{ml}$ was obtained for the following tests: fasting blood glucose, full blood counts, total serum cholesterol and lipid profile, serum creatinine, total bilirubin, and hepatic enzymes ALT, AST, gamma-GT, and ALP. These tests were repeated at the trial's end at 12 weeks. Thyroid stimulating hormone (TSH), and highly sensitive C-reactive protein (H-CRP) were also estimated at baseline and at 12 weeks.

Counselling for all participants included standard advice on diet, lifestyle, physical exercise, avoidance of smoking, moderation in consumption to participants taking alcohol, regular clinic attendance, and the need for prompt reporting of unusual symptoms or probable side-effects. The dose of caplets (Swastha Thriphala ${ }^{\circledR}$ or placebo) for all participants was 1 caplet in the morning and 2 caplets after dinner. The dose of Swastha Thriphala ${ }^{\circledR}$ was based on the expert advice of a team of senior Sri Lankan Ayurveda clinicians, and The Sri Lanka Ayurveda Pharmacopoiea [28] and The Ayurvedic Formulary of India [15].

Swatha Thriphala ${ }^{\circledR}$ contains three herbs by weight as follows: Terminalia chebula $318 \mathrm{mg}$, Terminalia bellerica $105 \mathrm{mg}$ and Phyllanthus emblica $211 \mathrm{mg}$. These three herbal ingredients are the same as in the centuries old traditional generic prescription. Preparation of the proprietary formulation uses a mixture of the dessicated fruits, with seeds removed, to a powder of particle size 75 to 150 microns, combined with a semi-solid isopropyl alcohol/water (70/30) extract of the fruits. The excipients, maize starch BP, carboxymethyl cellulose $\mathrm{BP}$, magnesium stearate $\mathrm{BP}$, and colloidal anhydrous silica BP are added to the mixture for preparing the caplets. Identical placebo caplets were made, using a mixture of the above excipients with a food-grade colouring agent to provide caplets of the same colour, weight and shape as the medicinal preparation. Over 10 million caplets of Swastha Thriphala ${ }^{\circledR}$ have been sold in Sri Lanka, for example, during year 2014.

Manufacture of Swastha Thriphala ${ }^{\circledR}$ is at a valid GMP certified facility. The G.M.P. certificate number is: Codex Alimentarius Commission, CAC/RCP 1-1969, Rev 4, authorised for Design, Development, Manufacture and Distribution of Ayurvedic herbal healthcare products, herbal personal care products, essential oils and oleoresins. 
The herbal product is standardised according to recommended qualitative tests and by regular High Performance Liquid Chromatography (HPLC). A typical HPLC fingerprint is given in the supplementary file. Standard operating procedures (SOPs) are followed at all stages of manufacture SOPs are as per G.M.P. certification.

Swastha Thriphala ${ }^{\circledR}$ and placebo caplets were packed in the required number of identical opaque plastic bottles numbered from 1 to 145 by a senior research scientist author, who had the list of computer derived random numbers for the trial $[18,19]$. After packing each bottle according to this list with either Swastha Thriphala ${ }^{\circledR}$ or placebo caplets, the list was placed in a sealed envelope until completion of the trial, when it was opened to give the statistics analysts the biochemical results, separately identified only as belonging to group A or B. Our trial started on $20^{\text {th }}$ December, 2014 and ended on $30^{\text {th }}$ March, 2016.

The Consultant Cardiologist who referred patients for the trial, the corresponding author who obtained consent, the technicians who obtained blood for biochemical tests and the statistics analysts were all blinded according to the accepted procedure $[20,21]$. The author who packed the bottles with Swastha Thriphala ${ }^{\circledR}$ or with placebo caplets, played no part in allocating the bottles of caplets to patients or in statistical analysis, which were done at completely different institutions, respectively the Faculty of Medicine, Colombo, and the Department of Statistics of the University of Colombo.

Sample size calculation was done using a formula for normal responses, taking the primary outcome as the total blood cholesterol from an internal pilot study of 30 patients, (standard deviation $=32.14 \mathrm{mg} / \mathrm{dl}) \quad[18]$. Taking the significance level $\alpha$ to be $5 \%(0.05)$ and power to be $1-\beta=80 \%$, and reference improvement to be 12.5 $\mathrm{mg} / \mathrm{dl}$, and using a sample size formula the size for one group was determined to be 104 [18,19]. This was increased to 114 for possible late withdrawals.

All significance tests used were based on the t-test assuming normal distribution of the response variable. If there were discrepancies in the distribution, the t-test was performed on $\log$ transformed data $[18,19]$.

Inclusion criteria were ages between 35 and 70 years, willingness to give witnessed and signed consent for participation, and for donating two venous blood samples of $10 \mathrm{ml}$. Exclusion criteria were clinical evidence of stroke, Parkinson disease, frailty, heart failure, chronic respiratory system disease, liver cirrhosis, or chronic kidney disease (eGFR below $40 \mathrm{ml} /$ hour).
Participants continued all medications prescribed for them by the Consultant Cardiologist and the Registrars at the Institute of Cardiology clinics during the trial period, and attended this clinic at the prescribed times. Clinical and biochemical pharmacovigilance for possible side-effects was maintained by mandatory monthly clinic visits, essential biochemical tests at the said clinic, and by an interview with the corresponding author for replenishing stocks of caplets and checking consumption at 6 weeks.

The decision to use Swastha Thriphala ${ }^{\circledR}$ in our study as an adjunct to atorvastatin in the first instance, rather than as the sole therapy, was taken for ethical reasons, so as not to deprive patients of their regular already proven therapy (atorvastatin) during the period of study. This study has been approved by the Ethics Review Committee of the SLMA (ERC/11-007), and registered with the Sri Lanka Clinical Trials Registry (APPL/2012/008). Swastha Thriphala ${ }^{\circledR}$ is registered as an Ayurveda Medicine (Registration No: 02/01/PA/15/142) with the Department of Ayurveda. Written informed consent was obtained from all participants. An independent Data and Drug Monitoring Group was appointed before recruitment of patients for the study.

\section{Results}

One hundred and ninety eight participants (Treatment Group 101, Control Group 97) completed the trial (Figure 1). The Treatment and Control Groups were similar in terms of age, height, and Body Mass Index at baseline (Table 1). There were no significant differences between the two groups at baseline regarding the biochemical variables that were measured in the study. Table 2 gives the comorbidities of the two groups at baseline. Among males eleven in the treatment group and 12 in the control group had stable angina. Among females 8 in the Treatment Group and 5 in the Control Group had stable angina. Among the participants with stable angina, 4 males in the Treatment Group, 5 males in the Control Group, and 2 females in each group, have had a myocardial infarction $6-8$ months prior to entering the trial. 3 . In all, 18 participants $(6 / 124$ males) and (12/74 females) had been stabilised on thyroxine for primary hypothyroidism prior to the trial period. Data show that the participants had taken atorvastatin $10 \mathrm{mg}$ daily over a wide range of durations varying from less than 7 up to 64 days before entering the trial, and that the comorbidities of the two groups were very similar at baseline (Table 3). 
Table 4 gives the biochemical variables of the Control Group at baseline and at 3 months. The serum total bilirubin has decreased $(p=0.05)$. All other biochemical variables only showed minor nonsignificant rises or decreases at 3 months.

In contrast, Table 5, which gives the biochemical data for the Treatment Group at baseline and at 3 months, shows significant falls in mean total blood cholesterol, mean cholesterol/HDL ratio, and in the mean non-HDL-cholesterol, from baseline values to the values at the end of 3 months. It also shows minor non-significant decreases in mean LDL, mean triglyceride content, and mean HS-CRP.

Table 6 gives the results of a head-to-head comparison of the differences in the means of the measured variables between their baseline values and corresponding values at 3 months of the Treatment and Control Groups. The decrease of the mean total blood cholesterol value and the non-HDL-cholesterol value of the Treatment Group are significantly greater $(p<0.0001)$ than the corresponding decrease in the Control Group. The decrease of the total cholesterol/HDL ratio in the Treatment Group between baseline and at 3 months is also significantly greater $(p<0.001)$ than the corresponding value of the Control Group.

Table 4 shows that in the Control Group mean non-HDL-C has increased significantly ( $p=0.05)$ from the baseline value at recruitment at the end of 3 months of the trial, whereas, in stark contrast, Table 5 shows a significant $(p<0.0001)$ reduction from the baseline value of mean non-HDL$\mathrm{C}$ in the Treatment Group at 3 months.

All other biochemical variables show nonsignificant rises or decreases at 3 months in both groups of patients.

There were no reports of adverse effects in participants of either the Treatment Group or Control Group. The side-effects reported by participants were nocturnal muscle cramps (12 participants in the Treatment Group and 10 in the Control Group), muscle pains on moderate exercise (18 participants in the Treatment Group and 15 in the Control Group), and occasional loose bowel motions (16 participants in the Treatment Group and 7 in the Control Group). Since these were minor side-effects, participants were counselled and reassured by telephone. None of the participants left the trial because of the reported side-effects or for any other reasons.

\section{Discussion}

In our study 198 patients receiving a maintenance dose of atorvastatin $10 \mathrm{mg}$ daily for lipid regulation from a tertiary care cardiology clinic completed the trial. The results of our trial show that among patients who took both Swastha Thriphala ${ }^{\circledR}$ and atorvastatin as stated above for three months, the reduction in total blood cholesterol as well as in the cholesterol/HDL ratio were statistically significant $(p<0.0001)$, whereas in the Control Group of patients who took atorvastatin and placebo caplets for 3 months, the reduction in total blood cholesterol was negligible $(p<0.28)$, and the cholesterol/HDL ratio was actually increased, albeit by a narrow and nonsignificant margin.

In the head-to-head comparison of the reduction of means between baseline and 3-month values of the two groups, the reductions of total cholesterol, total cholesterol/HDL ratio, and the nonHDL-C were significantly greater $(p<0.0001$, $p<0.001$ and $p<0.0001$ respectively) in the Treatment Group, than the corresponding reductions in the Control Group.

Perhaps the most important changes revealed in our trial pertain to the derived variable non-HDL-C in the two groups. Whereas in the Control Group the mean non-HDL-C has increased significantly $(p=0.05)$, in contrast, in the Treatment Group the mean non-HDL-C value has significantly $(p<0.0001)$ decreased at the end of the trial. Analysis of our data suggests clearly that thriphala has a beneficial effect on non-HDL-C over and above the benefits seen with only atorvastatin.

The non-HDL-C component of lipids consists mainly of highly atherogenic particles namely, intermediate density lipoprotein (ILDL), very low density lipoprotein (VLDL), dense LDL, apolipoprotein B and chylomicrons. Apolipoprotein B (apo B) is recognised as a risk factor of atherosclerotic disease, which may be superior in predictive value when compared to total and LDL cholesterol. Studies have shown that non-HDL-C is a simple surrogate of apo B levels, and that non-HDL$\mathrm{C}$ shows a higher correlation with atherosclerotic cardiovascular disease than apo B [23].

Although clinicians tend to focus on LDL levels for primary and secondary prevention of atherosclerotic cardiovascular disease, there is a significant residual risk of disease even after the LDL concentration reaches target levels, which emphasizes the need to have other parameters for control of dyslipidaemia [24]. The non-HDL-C value, which is derived from routine lipid profile data, provides a low cost and freely available metric [24]. Several studies demonstrate that both non- 
HDL-C and apo B levels are risk factors for major cardiovascular events even in patients already on atorvastatin [25].

There is strong evidence to support the assertion that in statin-treated patients, the strength of the association between LDL cholesterol and apolipoprotein B (apo B) with risk of future major cardiovascular events, is statistically weaker than the association of such events with non-HDL-C. Of the large number of publications that support this assertion, perhaps the meta-analysis among 38,153 patients allocated to statin therapy, and the two review articles should suffice [25-27].

Our clinical trials results provide compelling evidence for adding thriphala to the therapeutic regimen along with atorvastatin in patients at high risk of atherosclerotic vascular disease.

The side-effects thriphala reported by participants in our study were relatively few and minor, and similar in the two groups except for occasional loose bowel motions. They responded to reassurance given by the corresponding author by telephone. There were no significant changes in the biochemical variables pertaining to haematology, and hepatic and renal function in the Treatment Group of participants, and this observation too tends to confirm the several centuries old historical evidence of the safe use of thriphala. Compliance has been excellent as none of the 101 participants who started taking the test herbal medicine dropped out of the trial at any stage until its termination.

The results of our randomized control study show that Swastha Thriphala ${ }^{\circledR}$, a proprietary formulation of thriphala, when used as an adjunct to atorvastatin $10 \mathrm{mg}$ daily for cholesterol reduction, significantly enhances the lipid lowering effects of the statin, in patients taking it for lipid regulation. Our results indicate the need for a trial of Swastha Thriphala ${ }^{\circledR}$ as the sole therapy for lipid regulation, and for research into the mode of action of thriphala in reducing blood lipids.

\section{Acknowledgements}

We thank Link Natural Products (Pvt) Ltd and its Mr T.M.S. G. Tennekoon, Head R \&D and Q.A. Department, for financial support for the study and for providing Swastha Thriphala ${ }^{\circledR}$ and placebo caplets, and the local agents of Cipla Ltd for providing Atorlip ${ }^{\circledR}$ (atorvastatin $10 \mathrm{mg}$ ) from a single production batch for our study. We are grateful also to Professor Lal Chandrasena, of Nawaloka Metropolis Laboratories, for arranging to perform all the necessary biochemical investigations at concessionary rates. Ms Surangi Perera and Ms Saroja Ratnayake are thanked for their multiple contributions. We are extremely grateful to the patients who went with us all the way.

\section{Funding}

This study was sponsored by Link Natural Products (Pvt) Ltd which provided Swastha Thriphala ${ }^{\circledR}$ and placebo caplets. The local agents of Cipla Ltd provided Atorlip ${ }^{\circledR}$ (atorvastatin $10 \mathrm{mg}$.

\section{Conflicts of Interest}

CG is a Consultant to Link Natural Products (Pvt) Ltd for clinical investigations, and ADCSR is Senior R\&D Scientist at the same institution.

\section{References}

1. Goldine AB. Statins: is it really time to reassess benefits and risks? $N$ Engl J Med 2012; 366:1 752-55.

2. Beery J D, Alan Dyer, Xuan Cai, et al. Lifetime risks of cardiovascular disease. $N$ Engl J Med 2012; 366: 321-9.

3. British National Formulary. BMJ Group and Royal Pharmaceutical Society, London, UK 2014 - 2015. Cardiovascular System, p 84-89.

4. UNICEF/UNDP/WORLD BANK/WHO. Special Programme for Research and Training in Tropical Diseases. Operational guidance; information needed to support clinical trials of herbal products. TDR/GEN/GUIDANCE/05-1. WHO, Geneva, Switzerland, 2005.

5. Jayawardena MHS, de Alwis NMW, Hettigoda V, Fernando DJS. A double blind randomised placebo controlled cross over study of a herbal preparation containing Salacia reticulata in the treatment of type 2 diabetes. $J$ Ethnopharmacol 2005; 97: 215-9.

6. Jayashankar S, Panagoda GJ, Amaratunga EAPD, Perera K, Rajapakse PS. A randomised double-blind pacebo-controlled study on the effects of a herbal toothpaste on gingival bleeding, oral hygience and microbial variables. Ceylon Med J 2011; 56: 5-9.

7. Goonaratna C, Sooriyarachchi MR. the effect of a herbal formulation on the incidence and severity of upper respiratory symptoms in healthy volunteers: an open-label randomised clinical trial. Ceylon Med J 2012; 57: 19-32. 
8. Howshigan J, Perera K, Samita S, Rajapkse PS. The effects of an Ayurvedic medicinal toothpaste on clinical, microbial and oral hygiene parameters in patients with chronic gingivitis: a double-blind, randomised, placebocontrolled, parallel allocation clinical trial. Ceylon Med J 2011; 56: 5-9.

9. Ried K, Cohen C, Fakler P. Effect of garlic on serum lipids: an updated meta-analysis. Nutr Rev 2013; 71: 282-99.

10. Rohner A, Ried K, Sobenin IA, et al. A systematic review and meta-analysis of the effects of garlic preparations in individuals with hypertension Amer J Hyperten 2015; 28: 41423.

11. Baker WL, Gutierrez-Williams G, White CM, et al. Effect of cinnamon on glucose control and lipid parameters Diabetes Care 2008; 31: 41-3.

12. Allen RW, Schwartzman E, Coleman CI, et al. Cinnamon use in type 2 diabetes: an updated systematic review and meta-analysis. Ann Fam Med 2013; 11: 452-9.

13. Thakur CP, Singh R, Thakur B, et al. The Ayurvedic medicines Hartaki, Amla and Bahira reduce cholesterol-induced atherosclerosis in rabbits. Int J Card 1988; 21: 167-76.

14. Blumenthal M, Goldberg A, Brinkmann J, (Eds). Herbal Medicine: Expanded Commission (E) Monographs. Austin Tx: American Botanicals Council, Newton. Integrative Medicine Communications: 2000.

15. Ministry of Health and Family Planning. The Ayurvedic Formulary of India. Part I. Delhi 1978.

16. Tillotson A, Singh KP, Caldecott T. Thriphala. Can J Herbal 2001; 22: 16- 24.

17. Baliga MS, Meera S, Mathai B, et al. Scientific validation of ethnomedicinal properties of the Ayurvedic drug Thriphala: a review. Chin $J$ Integr Med 2012; 18: 946-54.
18. Pocock SJ. Clinical Trials: A Practical Approach. Wiley, Chichester, 1983.

19. Mead R, Curnow R, Hasted A. Statistical Methods in Agriculture and Experimental Biology. Third Edition (2002). CRC Press.

20. Schulz KF, Grimes DA. Blinding, who got what. Lancet 2002; 359: 696- 700.

21. Schulz KF, Chalmers I, Altman DG. The landscape and lexicon of blinding in clinical trials Ann Intern Med 2002; 136: 254-9.

22. Pilapitiya U. Traditional medicine Regional Health Forum 1996; 1: 51-2.

23. Hermans MP, Sacks FM, Sylvie AA, Rousseau MF. Non-HDL-cholesterol as valid surrogate to apolipoprotein $\mathrm{B}_{100}$ measurement in diabetes: Discriminant ratio and unbiased equivalence. Cardiovas Diabetology 2011: 10; 20-32.

24. Virani SS. Non-HDL cholesterol as a metric of good quality care. Texas Institute $J$ 2011; 38: 160-2.

25. Boekholdt SM, Arsenault BJ, Mora S, Pedersen TR, et al. Association of LDL cholesterol, nonHDL cholesterol, and apolipoprotein B levels with risk of cardiovascular events among patients treated with stains JAMA 2012; 307: 1302-9.

26. Pischon T, Girman GJ, Sacks FM, et al. Non-high density lipoprotein and apolipoprotein $\mathrm{B}$ in the prediction of coronary heart disease in men Circulation 2005; 112: 3375-83.

27. Brunzell JD, Davidson $\mathrm{M}$, Furberg $\mathrm{CD}$, et al. American Diabetes Association; American College of Cardiology Foundation. Lipoprotein management in patients with cardio metabolic risk. Consensus statement. Diabetes Care 2008; 31: 81122.

28. Department of Ayurveda. Ayurveda Pharmacopoiea. Vol 1; Part 1. Department of Ayurveda, Sri Lanka, 1976. 
Figure 1. Study flow diagram

Referred from Institute of

Cardiology, NHSL

$(n=237)$

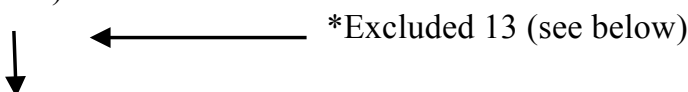

Assessed for eligibility

$(\mathrm{n}=224)$

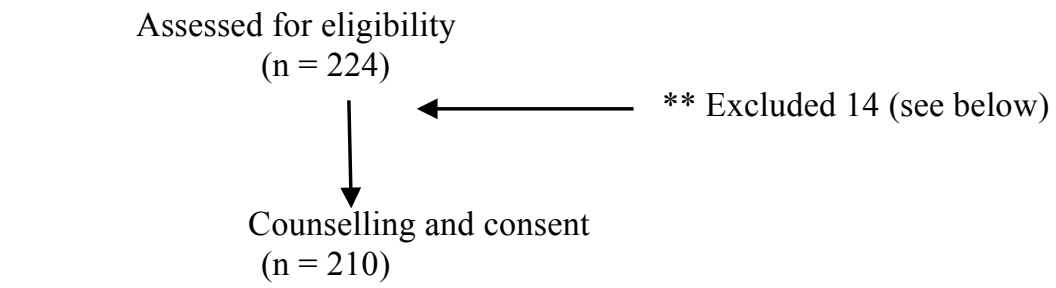

Swastha Thriphala ${ }^{\circledR}$

Treatment group $(n=105)$

** Started participation $(\mathrm{n}=101)$
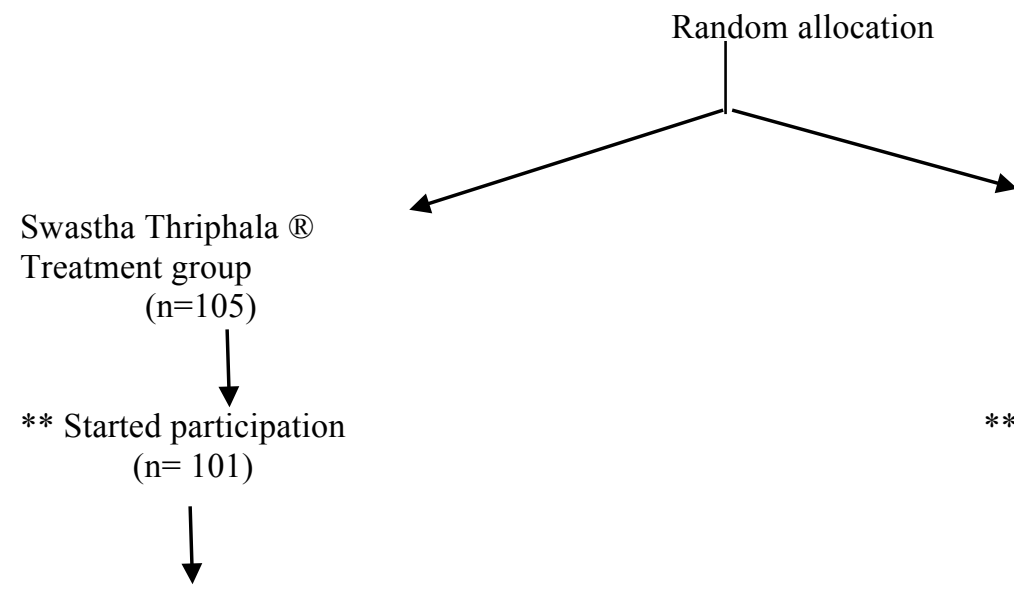

Data analysed $(\mathrm{N}=101)$

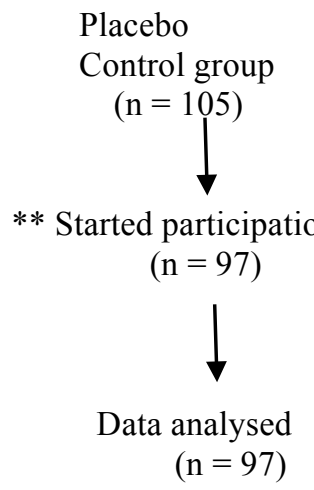

* Excluded $n=13$ : Reasons: had exclusion criteria

** Excluded $n=14$, and at a later stage, 4 and 8 participants for domestic/personal reasons unconnected with the study protocol. 
Table1. Study population details

\begin{tabular}{lccc}
\hline \multicolumn{1}{c}{ Variable } & Treatment Group & Control Group & $\begin{array}{c}\text { Significance } \\
\text { p value }\end{array}$ \\
\hline Male (n) & 60 & 64 & \\
Female (n) & 41 & 33 & 0.64 \\
\hline Age (years) mean \pm SD & $58 \pm 7.9$ & $58 \pm 6.6$ & 0.41 \\
Age (years) range & $35-69$ & $42-70$ & \\
Height $(\mathrm{cm})$ mean $+\mathrm{SD}$ & $155.5 \pm 8.6$ & $156.4 \pm 7.9$ & \\
\hline & $135-175$ & $140-177.5$ & 0.06 \\
\hline Height $(\mathrm{cm})$ range & $25.3 \pm 4.2$ & $26.4 \pm 4.2$ & \\
\hline
\end{tabular}


Table 2. Relevant comorbidities in treatment and control groups

Relevant comorbidities

\begin{tabular}{lcc}
\hline & $\begin{array}{c}\text { Treatment } \\
\text { Group }\end{array}$ & Control Group \\
\hline Primary hypertension only (males) & 30 & 32 \\
\hline Primary hypertension only (females) & 19 & 16 \\
\hline $\begin{array}{l}\text { Primary hypertension and diabetes } \\
\text { (males) }\end{array}$ & 19 & 20 \\
\hline $\begin{array}{l}\text { Primary hypertension and diabetes } \\
\text { (females) }\end{array}$ & 14 & 12 \\
\hline $\begin{array}{l}\text { Primary hypertension, diabetes and } \\
\text { stable angina (male) }\end{array}$ & 11 & 12 \\
\hline $\begin{array}{l}\text { Primary hypertension, diabetes and } \\
\text { stable angina (females) }\end{array}$ & 8 & 57 \\
\hline Total & 101 & \\
\hline
\end{tabular}


Table 3. Duration of atorvastatin therapy at entry to trial

Duration (Days) Number of participants $(n=198)$

\begin{tabular}{cc}
$<7$ & 19 \\
\hline $8-14$ & 27 \\
\hline $15-21$ & 31 \\
\hline $22-28$ & 31 \\
\hline $29-35$ & 30 \\
\hline $36-24$ & 31 \\
\hline $43-49$ & 11 \\
\hline $50-56$ & 7 \\
\hline $57-63$ & 7 \\
\hline$\geq 64$ & 4 \\
\hline
\end{tabular}


Table 4. Summary of laboratory data of participants: Control Group

\begin{tabular}{|c|c|c|c|c|c|c|c|}
\hline & \multirow[t]{2}{*}{ Variable } & \multicolumn{2}{|c|}{ At recruitment } & \multicolumn{2}{|l|}{ At 3 months } & \multirow[t]{2}{*}{ t value } & \multirow[b]{2}{*}{$\begin{array}{l}\text { Recruitment } \\
\text { vs. three } \\
\text { months } \\
\text { p value ( } \alpha= \\
0.05)\end{array}$} \\
\hline & & $\begin{array}{l}\text { Actual data } \\
(\text { Mean } \pm \text { SD })\end{array}$ & $\begin{array}{l}\text { Log transformed } \\
\text { data } \\
(\text { Mean } \pm \text { SD) }\end{array}$ & $\begin{array}{l}\text { Actual data } \\
(\text { Mean } \pm \text { SD })\end{array}$ & $\begin{array}{l}\text { Log transformed } \\
\text { data }(\text { Mean } \pm \text { SD) }\end{array}$ & & \\
\hline 1 & $\begin{array}{l}\text { Mean total cholesterol } \\
(\mathrm{mg} / \mathrm{dL})\end{array}$ & $164.4 \pm 34.8$ & & $167.49 \pm 34.0$ & & 1.09 & 0.279 \\
\hline 2 & Mean HDL (mg/dL) & $47.7 \pm 14.6$ & & $49.3 \pm 44.5$ & & 0.35 & 0.72 \\
\hline 3 & Mean LDL (mg/dL) & $89.6 \pm 25.9$ & & $92.4 \pm 27.5$ & & 1.02 & 0.31 \\
\hline 4 & $\begin{array}{l}\text { Mean Non-HDL } \\
\text { cholesterol }(\mathrm{mg} / \mathrm{dL})\end{array}$ & $116.7 \pm 35.6$ & & $122.5 \pm 34.9$ & & -1.97 & 0.05 \\
\hline 5 & Mean triglyceride (mg/dL) & $117.9 \pm 61.6$ & & $122.8 \pm 55.1$ & & 0.87 & 0.38 \\
\hline 6 & $\begin{array}{l}\text { Mean total } \\
\text { cholesterol/HDL }\end{array}$ & $3.72 \pm 1.54$ & & $3.88 \pm 1.24$ & & -0.98 & 0.33 \\
\hline 7 & Mean HS- CRP (mg/L) & $1.62 \pm 1.99$ & & $2.38 \pm 4.72$ & & -1.54 & 0.13 \\
\hline 8 & Mean AST (IU/L) & $28.0 \pm 12.7$ & & $27.0 \pm 11.7$ & & -0.96 & 0.34 \\
\hline 9 & $\begin{array}{l}\text { Mean fasting blood } \\
\text { glucose }(\mathrm{mg} / \mathrm{dL})^{*}\end{array}$ & $116.6 \pm 40.8$ & $4.71 \pm 0.28$ & $117.1 \pm 41.5$ & $4.71 \pm 0.28$ & -0.21 & 0.83 \\
\hline 10 & Mean creatinine $(\mathrm{mg} / \mathrm{dL}) *$ & $1.02 \pm 0.29$ & $-0.02 \pm 0.28$ & $1.01 \pm 0.26$ & $-0.02 \pm 0.26$ & 0.24 & 0.81 \\
\hline 11 & Mean ALT (IU/L)* & $52.3 \pm 25.1$ & $3.88 \pm 0.36$ & $50.6 \pm 21.8$ & $3.86 \pm 0.32$ & 0.65 & 0.51 \\
\hline 12 & $\begin{array}{l}\text { Mean alkaline } \\
\text { phosphatase }(\mathrm{IU} / \mathrm{L}) *\end{array}$ & $93.6 \pm 27.5$ & $4.50 \pm 0.28$ & $89.3 \pm 25.7$ & $4.45 \pm 0.28$ & 2.31 & 0.02 \\
\hline 13 & Mean gamma GT (IU/L)* & $44.6 \pm 27.6$ & $3.63 \pm 0.56$ & $42.5 \pm 26.1$ & $3.60 \pm 0.53$ & 1.46 & 0.15 \\
\hline 14 & Mean bilirubin $(\mathrm{mg} / \mathrm{dL}) *$ & $0.81 \pm 0.40$ & $-0.31 \pm 0.44$ & $0.78 \pm 0.40$ & $-0.36 \pm 0.45$ & 1.98 & 0.05 \\
\hline
\end{tabular}

Notes: * Parameters transformed to log scale to achieve normal distribution. HS-CRP $=$ Highly sensitive C-reactive protein; AST $=$ Aspartate aminotransferase; ALT $=$ Alanine aminotransferase; HDL = High density lipoprotein; LDL= Low density lipoprotein. 29 
Table 5. Summary of laboratory data of participants. Treatment Group

\begin{tabular}{|c|c|c|c|c|c|c|c|}
\hline & \multirow[b]{2}{*}{ Variable } & \multicolumn{2}{|l|}{ At recruitment } & \multicolumn{2}{|l|}{ At 3 months } & \multirow[b]{2}{*}{ t value } & \multirow[b]{2}{*}{$\begin{array}{l}\text { Recruitment vs } \\
\text { three months } \\
\text { p value }\end{array}$} \\
\hline & & $\begin{array}{l}\text { Actual data (Mean } \\
\pm \text { SD) }\end{array}$ & $\begin{array}{l}\text { Log transformed } \\
\text { data (Mean } \pm \\
\text { SD) }\end{array}$ & $\begin{array}{l}\text { Actual data } \\
(\text { Mean } \pm \text { SD) }\end{array}$ & $\begin{array}{l}\text { Log } \\
\text { transformed } \\
\text { data (Mean } \pm \\
\text { SD) } \\
\end{array}$ & & \\
\hline 1 & Mean total cholesterol (mg/dL) & $175.1 \pm 32.1$ & & $153.1 \pm 27.5$ & & -8.79 & $<0.0001$ \\
\hline 2 & Mean HDL (mg/dL) & $48.3 \pm 13.7$ & & $48.2 \pm 14.5$ & & -0.15 & 0.88 \\
\hline 3 & Mean LDL (mg/dL) & $86.5 \pm 24.2$ & & $84.0 \pm 19.9$ & & -1.18 & 0.24 \\
\hline 4 & Mean Non-HDL cholesterol (mg/dL) & $126.7 \pm 30.7$ & & $104.8 \pm 27.0$ & & 8.85 & $<0.0001$ \\
\hline 5 & Mean triglyceride $(\mathrm{mg} / \mathrm{dL})$ & $108.4 \pm 53.3$ & & $104.8 \pm 47.9$ & & -0.81 & 0.42 \\
\hline 6 & Mean total cholesterol/HDL & $3.801 \pm 1.06$ & & $3.386 \pm 0.94$ & & -5.9 & $<0.0001$ \\
\hline 7 & Mean HS-CRP (mg/L) & $2.34 \pm 2.78$ & & $2.31 \pm 2.44$ & & -0.10 & 0.92 \\
\hline 8 & Mean AST (IU/L) & $31.1 \pm 15.0$ & & $30.4 \pm 16.4$ & & -0.63 & 0.53 \\
\hline 9 & Mean fasting blood glucose $(\mathrm{mg} / \mathrm{dL}) *$ & $112.7 \pm 36.2$ & $4.68 \pm 0.27$ & $113.3 \pm 37.4$ & $4.68 \pm 0.27$ & -0.27 & 0.78 \\
\hline 10 & Mean creatinine $(\mathrm{mg} / \mathrm{dL}) *$ & $0.98 \pm 0.27$ & $-0.05 \pm 0.26$ & $0.97 \pm 0.25$ & $-0.06 \pm 0.25$ & 0.71 & 0.48 \\
\hline 11 & Mean ALT (IU/L)* & $49.4 \pm 16.6$ & $3.85 \pm 0.28$ & $50.5 \pm 15.9$ & $3.87 \pm 0.28$ & -0.97 & 0.33 \\
\hline 12 & Mean alkaline phosphatase (IU/L) * & $98.7 \pm 26.9$ & $4.56 \pm 0.26$ & $93.9 \pm 26.5$ & $4.50 \pm 0.27$ & 2.93 & 0.004 \\
\hline 13 & Mean gamma GT (IU/L)* & $41.1 \pm 25.9$ & $3.63 \pm 0.59$ & $40.2 \pm 23.0$ & $3.61 \pm 0.59$ & 1.05 & 0.29 \\
\hline 14 & Mean bilirubin $(\mathrm{mg} / \mathrm{dL}) *$ & $0.79 \pm 0.37$ & $-0.34 \pm 0.44$ & $0.83 \pm 0.54$ & $-0.32 \pm 0.40$ & -0.53 & 0.60 \\
\hline
\end{tabular}

Note: * Parameters transformed to log scale to achieve normal distribution. HS-CRP $=$ Highly sensitive C-reactive protein; AST=Aspartate aminotransferase; ALT $=$ Alanine aminotransferase; HDL $=$ High density lipoprotein; $\mathrm{LDL}=$ Low density lipoprotein. 30 
Table 6. Summary of laboratory data of participants: Treatment Group vs Control Group

\begin{tabular}{|c|c|c|c|c|c|}
\hline & Variable & $\begin{array}{l}\text { Mean at } 3 \text { months-mean at } \\
\text { recruitment }\end{array}$ & $\begin{array}{c}\text { Mean at } 3 \text { months-mean at } \\
\text { recruitment }\end{array}$ & t value & $\begin{array}{c}\text { Treatment Group vs } \\
\text { Control Group p } \\
\text { value } \\
\end{array}$ \\
\hline 1 & Total cholesterol $(\mathrm{mg} / \mathrm{dL})$ & -22.000 & 3.124 & 6.583 & $<0.0001$ \\
\hline 2 & HDL (mg/dL) & -0.117 & 1.659 & 0.366 & 0.357 \\
\hline 3 & LDL $(\mathrm{mg} / \mathrm{dL})$ & -2.521 & 2.742 & 1.527 & 0.063 \\
\hline 4 & Total Non-HDL cholesterol (mg/dL) & -21.881 & 6.061 & -8.040 & $<0.0001$ \\
\hline 5 & Triglyceride $(\mathrm{mg} / \mathrm{dL})$ & -3.574 & 4.814 & 1.180 & 0.119 \\
\hline 6 & Total cholesterol/HDL & -0.416 & 0.180 & -3.330 & 0.001 \\
\hline 7 & HS-CRP (mg/L) & -0.020 & 0.770 & -1.380 & 0.169 \\
\hline 8 & AST (IU/L) & -0.700 & -1.000 & -0.129 & 0.551 \\
\hline 9 & Fasting blood glucose $(\mathrm{mg} / \mathrm{dL}) *$ & 0.000 & 0.000 & 0.000 & 1.000 \\
\hline 10 & Creatinine $(\mathrm{mg} / \mathrm{dL}) *$ & -0.009 & -0.005 & 0.172 & 0.864 \\
\hline 11 & $\operatorname{ALT}(\mathrm{IU} / \mathrm{L}) *$ & -0.024 & 0.0143 & -1.160 & 0.247 \\
\hline 12 & Alkaline phosphatase (IU/L) * & 0.051 & 0.041 & 0.454 & 0.650 \\
\hline 13 & Gamma GT (IU/L) * & 0.020 & 0.030 & -0.223 & 0.823 \\
\hline 14 & Bilirubin $(\mathrm{mg} / \mathrm{dL}) *$ & -0.015 & 0.050 & -1.719 & 0.087 \\
\hline
\end{tabular}

Notes: * Parameters transformed to log scale to achieve normal distribution. HS-CRP $=$ Highly sensitive C-reactive protein; AST $=$ Aspartate aminotransferase; $\mathrm{ALT}=$ Alanine aminotransferase; HDL $=$ High density lipoprotein; $\mathrm{LDL}=$ Low density lipoprotein.

This is an open-access article distributed under the terms of the Creative Commons Attribution License, which permits unrestricted use, distribution, and reproduction in any medium, provided the original author and source are credited. 